\title{
INGESTIVE BEHAVIOR OF BUFFALOES FED INCREASING LEVELS OF CONCENTRATE IN SUGARCANE BASED DIETS
}

Ricardo Alexandre Silva Pessoa, Francisco Fernando Ramos de Carvalho, Djalma Euzébio Simões Neto, Matheus Rocha do Carmo, Sánara Adrielle França Melo, Maria Luciana Menezes Wanderley Neves, Guilherme Heliodoro Pedroso Vieira, Rennan Tavares Cordeiro Galvão

Universidade Federal Rural de Pernambuco - UFPE. E-mail: ricardo.spessoa@ufrpe.br

\begin{abstract}
The experiment was conducted to evaluate the ingestive behavior of buffalo fed sugarcane with different levels of concentrate. Twenty four Murrah buffaloes with body weight of $219 \pm 23 \mathrm{~kg}$ and nine months old were assigned to completely randomized design. Animals were placed in individual pens where they received diets ad libitum, twice a day. The experimental period has divided into $30 \mathrm{~d}$ for adaptation and 84 d for observations and samples collection. Four treatments were used: 1) $80 \%$ sugarcane (SC) $+20 \%$ concentrate (C); 2) $60 \%$ SC $+40 \%$ C; 3) $40 \%$ SC + 60\% C; 4) $20 \%$ SC $+80 \%$ C. The diets were isoproteics and urea/ammonium sulfate was used at 9:1 ratio to correct the protein level of sugarcane. The evaluated variables were time spent feeding (TSF), ruminating (TSR), idle (TSI), dry matter intake (DMI), feeding efficiency of dry matter $\left(\mathrm{FE}_{\mathrm{DM}}\right)$, rumination efficiency of dry matter $\left(\mathrm{RE}_{\mathrm{DM}}\right)$, number of meals, duration of meal and duration of breaks between meal. A regression analysis was performed using the MIXED procedure. DMI was positively affected $(P<0.05)$ by concentrate levels. The treatments had no effect $(P>0.05)$ on TSF. However, the TSR and number of meals decreased linearly $(P<0.05)$ as the dietary levels of concentrate increased. TSI, duration of meal and duration of breaks between meals increased linearly $(\mathrm{P}<0.05)$. Increasing levels of concentrate up to $80 \%$ in sugarcane based diets influence directly the feeding behavior of buffaloes resulting in fewer daily meals and more time in the trough, improving the feeding and rumination efficiencies.
\end{abstract}

Keywords: Bubalus bubalis; feeding efficiency; meals; rumination; Saccharum officinarum

\section{Comportamento ingestivo de búfalos alimentados com níveis crescentes de concentrado em dietas com} cana-de-açúcar

\section{Resumo}

O experimento foi conduzido para avaliar o comportamento ingestivo de búfalos alimentados com cana-deaçúcar e diferentes níveis de concentrado. Vinte e quatro búfalos Murrah com peso corporal de $219 \pm 23 \mathrm{~kg}$ e nove meses de idade foram distribuídos em delineamento inteiramente casualizado. Os animais foram manejados em baias individuais, onde receberam dietas ad libitum, duas vezes ao dia. 0 período experimental foi dividido em 30 dias para adaptação e 84 dias para observações e coleta de amostras. Foram utilizados quatro tratamentos: 1) $80 \%$ de cana-de-açúcar (SC) $+20 \%$ de concentrado (C); 2 ) $60 \%$ SC + $40 \%$ C; 3) $40 \%$ SC $+60 \%$ C; 4) $20 \%$ SC $+80 \%$ C. As dietas foram isoproteicas e uma mistura de ureia/sulfato de amônio na proporção de 9:1 foi utilizada para corrigir o nível de proteína da cana-de-açúcar. As variáveis avaliadas foram: tempo gasto na alimentação (TSF), ruminação (TSR), ócio (ETI), consumo de matéria seca (DMI), eficiência alimentar em função do consumo de matéria seca (FEDM), eficiência da ruminação em função do consumo de matéria seca (REDM), número de refeições, duração da refeição e duração dos intervalos entre as refeições. Uma análise de regressão foi realizada usando o procedimento MIXED. O DMI foi afetado positivamente $(P<0,05)$ pelos níveis de concentrado. Os tratamentos não tiveram efeito $(P>0,05)$ no TSF. No entanto, o TSR e o número de refeições diminuíram linearmente $(P<0,05)$ à medida que os níveis alimentares de concentrado aumentaram. A ETI, a duração da refeição e a duração dos intervalos entre as refeições aumentaram linearmente $(P<0,05)$. Níveis crescentes de concentrado em até $80 \%$ em dietas à base de cana-de-açúcar influenciam diretamente o comportamento alimentar dos búfalos, 
resultando em menos refeições diárias e mais tempo no cocho, melhorando a eficiência de alimentação e de ruminação.

Palavras-chave: Bubalus bubalis; eficiência alimentar; refeições, ruminação; Saccharum officinarum

\section{Introduction}

Buffalo is increasingly becoming popular in several parts of the world because of its superior quality of milk, better ability to adapt to different climates and to poor quality crop residue based fibrous diets and their high fertility rates (PAUL; LAL, 2010). The highest growth rate in buffalo population has been recorded in the American continent where its number is growing at a rhythm of $12.7 \%$ per year (PAUL, 2011). It can be estimated that the buffalo population in Brazil is something between 3.0 and 3.5 millions of animals, distributed in about 25.000 herds in all regions of the country, usually in small and medium farms, having a bigger concentration (62\%) in the North region, mainly destinated to meat production. However, from years 80/90, there has been a growing interest in milk or double purpose exploration (meat and milk) (BERNARDES, 2007). From 2007 to 2008, the buffalo herd in the northeast region of Brazil increased by $12.5 \%$ against $0.5 \%$ for the cattle herd, demonstrating the growing interest in raising buffalo (ARAÚJO et al., 2012).

Usually the buffaloes explorations are made under extensive systems having as alimentary base native or cultivated tropical pastures and most of the time without the concentrated food. The forage supplementation is made very often in the worst feeding season, especially the sugarcane (BERNARDES, 2007). For the efficient use of a food alternative, it is necessary to know the physiological mechanisms of the animals involved and their feeding behavior, as these factors directly affect productive performance (SILVA et al., 2016).

Research information about the sugarcane in buffalo feed are scarce. Sugarcane is a tropical roughage, poor in crude protein but high in dry matter production. Is traditionally used in Brazil because its production coincides with the period of forage scarcity (MARIZ et al., 2013). However, sugarcane fiber has a low digestibility and may have a depressing effect on feed intake. Best animal performance has been observed using sugarcane as a roughage source in high-concentrate diets.
The ingestive behavior of ruminants has been studied for a long time. Understanding of ingestive behavior in different roughage/concentrate ratios is essential for the development of management strategies aiming to optimize animal production. The ingestive activities are concentrated in discrete periods during the day, heterogeneously distributed over the circadian period (SILVA et al., 2008) and the diet composition affect theses activities. Based on the hypothesis that different concentrate levels in sugarcane based diets modify the ingestive behavior of animals, the aim of this study was to evaluate the ingestive behavior and the meal dynamics of Murrah buffaloes fed increasing levels of concentrate.

\section{Material and Methods}

The experiment was performed at the Animal Science Department located in Federal Rural University of Pernambuco, Recife, Brazil. The management and care of animals were performed according to the guidelines and recommendations of the Committee of Ethics on Animal Use (CEUA - license 075/2015, UFRPE). Twenty-four animals, with a mean age of 9 months and an initial body weight of $240 \pm 50.5$ $\mathrm{kg}$, were distributed to four treatments: $20 \%$ concentrate and $80 \%$ sugarcane, $40 \%$ concentrate and $60 \%$ sugarcane, $60 \%$ concentrate and $40 \%$ sugarcane, and $80 \%$ concentrate and $20 \%$ sugarcane. The animals were assigned to a completely randomized design to evaluate the ingestive behavior, the feed and rumination efficiencies and meal dynamic. The animals were coming from the same farm and were housed in individual stalls $\left(4 \mathrm{~m}^{2} /\right.$ animal) in a covered confinement shed, with free access to an individual's feeder and drinking fountain.

The animals were fed ad libitum in the form of complete diet, twice daily $(08.00$ and $16.00 \mathrm{~h}$ ), containing levels of $20,40,60$ and $80 \%$ of concentrate on the dry matter basis (DM) associate to sugarcane (Saccharum officinarum L.) corrected with urea (Tables 1 and 2). The orts were weighed daily to obtain a maximum of $10 \%$ of total feed provided. The concentrates were 
composed of corn, wheat bran, soybean meal

and mineral mixture. The diets were isoprotein.

Table 1. Chemical composition of the ingredients in the experimental diets.

\begin{tabular}{lrrrrr}
\hline & \multicolumn{5}{c}{ Ingredients } \\
\cline { 2 - 6 } Items & Sugarcane & Corn & $\begin{array}{c}\text { Soybean } \\
\text { meal }\end{array}$ & $\begin{array}{c}\text { Wheat } \\
\text { bran }\end{array}$ & Ureia \\
\hline Dry matter & 34.0 & 88.3 & 89.1 & 89.7 & 98.3 \\
Organic matter & 97.2 & 97.7 & 92.7 & 92.3 & 99.9 \\
Crude protein & 2.7 & 8.9 & 49.7 & 17.7 & 265.4 \\
Ether extract & 1.3 & 4.0 & 1.9 & 3.3 & -- \\
Neutral detergent fiber & 54.3 & 13.5 & 15.2 & 44.8 & -- \\
Indigestible neutral detergent fiber & 21.3 & 1.4 & 2.0 & 4.9 & -- \\
Non-fiber carbohydrates & 38.9 & 71.3 & 25.9 & 26.5 & - \\
\hline
\end{tabular}

Table 2. Ingredients proportion and chemical compositions of the experimental diets.

\begin{tabular}{lrrrr}
\hline & \multicolumn{4}{c}{ Concentrate levels (\%) } \\
\cline { 2 - 5 } Items & 20 & 40 & 60 & 80 \\
\hline Ingredients (g/kg of DM) & & & & \\
Sugarcane & & & & \\
Corn & 92.5 & 1900.0 & 400.0 & 200.0 \\
Soybean meal & 5.0 & 10.0 & 287.5 & 385.0 \\
Wheat bran & 92.5 & 190.0 & 287.5 & 385.0 \\
Mineral mix & 10.0 & 10.0 & 10.0 & 10.0 \\
Chemical composition (g/kg of DM) & & & & \\
Dry matter (g/kg) & 461.7 & 566.5 & 671.4 & 776.3 \\
Organic matter & 958.8 & 954.1 & 949.4 & 944.7 \\
Crude protein & 132.8 & 134.8 & 136.8 & 138.8 \\
Ether extract & 16.8 & 21.5 & 26.3 & 31.0 \\
Neutral detergent fiber & 471.7 & 425.1 & 378.4 & 331.8 \\
Indigestible neutral detergent fiber & 169.5 & 134.9 & 100.2 & 65.6 \\
Non-fiber carbohydrates & 337.6 & 372.8 & 408.0 & 443.2 \\
\hline
\end{tabular}

${ }^{1}$ Sugarcane corrected with urea/ammonium sulfate (96.0\% sugarcane and $4.0 \%$ urea/as)

The experimental period lasted 114 days and was divided into a 30-day adaptation period (when the animals were treated against ecto and endoparasites and received supplementation of $A, D$ and $E$ vitamins) and 84 days for data and sample collection. The dry matter intake (DMI) was evaluated during 84 days with samples of ingredients and orts daily collected.

Dry matter (DM), organic matter (OM), and crude protein $(\mathrm{CP})$ analyses were performed according to the AOAC (1990), method number 934.01 for DM, 930.05 for OM, and 981.10 for CP. Ether extract (EE) was analyzed by Soxhlet extraction with petroleum ether, according to the AOAC (1990), method number 920.39. The concentration of neutral detergent fiber (NDF) was assayed with heat-stable amylase and corrected for ash and nitrogen compounds
[aNDFom $(\mathrm{n})$ ] by using techniques described by Mertens (2002), with corrections for protein according to Licitra et al. (1996) and thermostable alpha-amylase added. Non-fiber carbohydrates (NFC) were calculated according to Hall (2000), as follows:

NFC $\left(\mathrm{g} / \mathrm{kg}^{-1}\right)=1000-[(\mathrm{CP}-$ urea-derived $\mathrm{CP}+$ urea) $\left.+\mathrm{NDF}_{\mathrm{ap}}+\mathrm{EE}+\mathrm{ash}\right]$,

in which $\mathrm{CP}=$ crude protein; $\mathrm{NDF}_{\mathrm{ap}}=$ neutral detergent fiber corrected for ash and protein; and $\mathrm{EE}=$ ether extract. To determine indigestible neutral detergent fiber $\left(N D F_{i}\right)$ samples of all foods were incubated in the rumen of a buffalo for 288 hours, as suggested by Detmann et al. (2012).

Ingestive behavior activities - times spent on feeding (TSF), rumination (TSR) and idleness (TSI) - were measured by direct visual 
observation (six observers) every 5 minutes for 24 hours, twice, during the period for data and sample collection (Bürger et al., 2000). TSF was considered as the time selecting and consuming the diet. TSR was considered as the period in which the animal was not feeding, but rechewing the cud (observed by the lateral movement of the mouth and the flow of food bolus via the esophagus). TSI represented the period where the animals was not eating or ruminating. The activities were recorded as total time per day ( $\mathrm{min} /$ day) and the ingestive behavior variables were obtained using the equations from Bürger et al. (2000). The feed and rumination efficiencies were obtained according to the following equations:

feed efficiency of DM ( $\left.\mathrm{FE}_{\mathrm{DM}}\right)=\mathrm{DMI} / \mathrm{TSF}$; rumination efficiency of $\mathrm{DM}\left(\mathrm{RE}_{\mathrm{DM}}\right)=$ $\mathrm{DMI} / \mathrm{TSR}$,

in which $\mathrm{FE}(\mathrm{kg} \mathrm{DM} / \mathrm{h})$ is feed efficiency, DMI ( $\mathrm{kg}$ $\mathrm{DM} /$ day) is $\mathrm{DM}$ intake and $\mathrm{RE}(\mathrm{kg} \mathrm{DM} / \mathrm{h})$ is rumination efficiency.

During the behavior evaluation period ( 24 hours), the environment was monitored (temperatures and the relative humidity of the air). The minimum and maximum temperatures observed were 23.3 and 29.9 으, respectively. The average relative humidity of the air was $69.0 \%$.
The number and duration (in minutes) of meals and the interval between meals was calculated. A meal was considered a long sequence of feeding with at least two successive 5 -minute feeding periods. The minimum interval between meals was considered to be 20 minutes.

Variance analysis was conducted in a completely randomized design with four treatments $(20,40,60$, and $80 \%)$ and six animals per treatment. Initial body weight was used as a covariate in the statistical model, using the PROC GLM procedure of SAS, according to the following model:

$$
Y_{i} \mathrm{j}=\mu+T i+\beta(X i j-X)+e i j,
$$

where $Y_{i j}$ is the observed dependent variable; $\mu$ is the overall mean; $T i$ is the effect of treatment ( $i=1$ to 4$) ; \beta(X i j-X)$ is the effect of co-variable; and $e \mathrm{ij}$ is the experimental error. The comparisons between the studied levels were decomposed orthogonally of the square sums associated with the variation in linear and quadratic effects, and the PROC GLM procedure of SAS, adopting $\alpha=0.05$, was conducted.

\section{Results and Discussion}

A positive linear effect $(P<0.05)$ was observed for DMI with the different levels of concentrate inclusion (Figure 1).

Figure 1. DMI of buffaloes fed increasing levels of concentrate in sugarcane based diets.

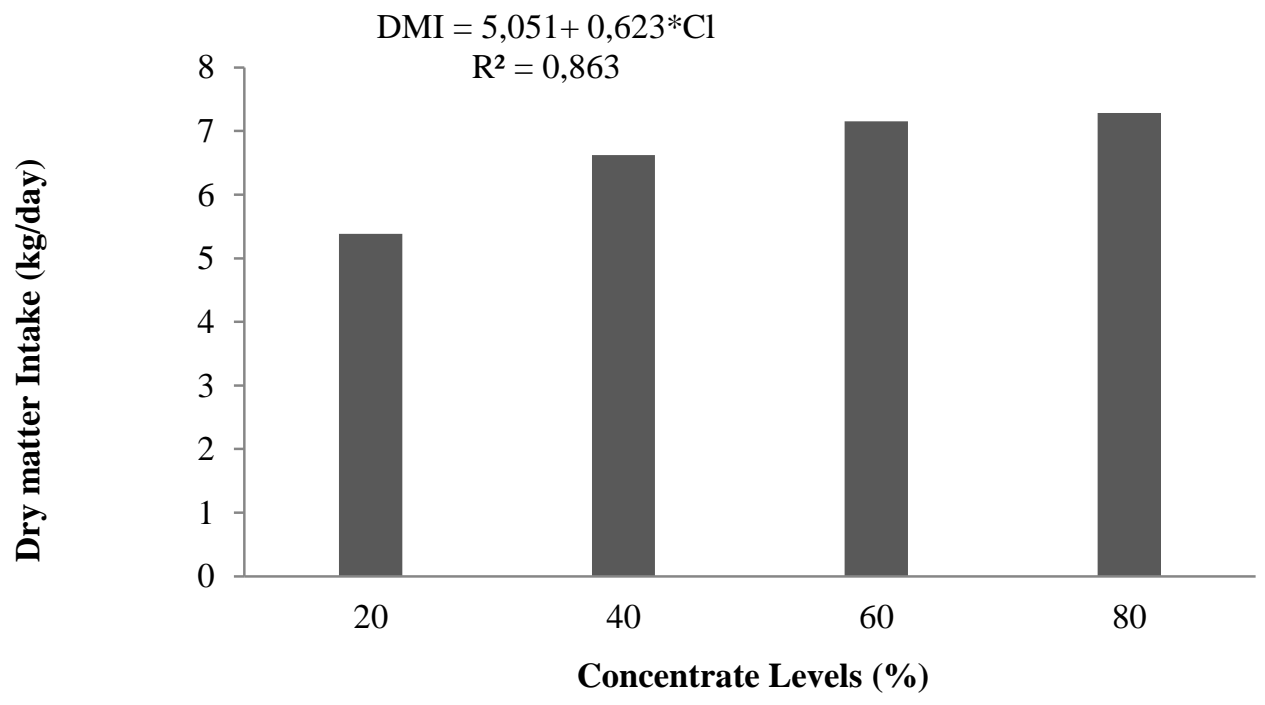

This behavior can be understood because greater proportion of concentrate in sugarcane based diets results in higher degradation rates in the rumen and consequently greater DMI. On the other hand, sugarcane fiber's low digestibility is largely responsible for tract fill, causing intake reductions (CORREA et al., 2003). 
It was not observed significant differences $(P>0.05)$ for the TSF. On the other hand, the TSR reduced linearly $(P<0.05)$ with the treatments. Consequently, the TSI increased

Table 3. Measures of ingestive behavior of buffaloes fed increasing levels of concentrate in sugarcane based diets.

\begin{tabular}{|c|c|c|c|c|c|c|c|}
\hline \multirow{2}{*}{ Activities } & \multicolumn{4}{|c|}{ Concentrate levels (\%) } & \multirow{2}{*}{ SEM } & \multicolumn{2}{|c|}{$P$ value } \\
\hline & 20 & 40 & 60 & 80 & & Linear & Quadratic \\
\hline TSF (min/day) & 188.3 & 180.0 & 175.0 & 169.0 & 6.9 & 0.30 & 0.93 \\
\hline TSFDM $(\mathrm{min} / \mathrm{kg} \mathrm{DM})^{1}$ & 36.5 & 27.5 & 25.1 & 23.6 & 18.1 & 0.01 & 0.22 \\
\hline TSR (min/day) ${ }^{2}$ & 495.0 & 499.0 & 498.3 & 356.0 & 17.7 & 0.00 & 0.07 \\
\hline $\operatorname{TSRDM}(\mathrm{min} / \mathrm{kg} \mathrm{DM})^{3}$ & 96.3 & 77.7 & 70.7 & 50.0 & 5.3 & 0.00 & 0.89 \\
\hline TSI (min/day) ${ }^{4}$ & 756.7 & 761.0 & 766.7 & 915.0 & 21.2 & 0.01 & 0.06 \\
\hline
\end{tabular}

SEM standard error of the mean

TSF - times spent on feeding; TSFDM - times spent on feeding/dry matter: TSR - times spent on rumination; TSRDM times spent on rumination/dry matter; TSI - times spent on idleness

$\hat{Y}=178.1 ;{ }^{1} \hat{Y}=38.4-4.12 X ;{ }^{2} \hat{Y}=566.5-2.1 X ;{ }^{3} \hat{Y}=110.11-14.58 X ;{ }^{4} \hat{Y}=679.7+2.4 X$

Gonçalves et al. (2001), in experiment with goats fed diets with different forage:concentrate ratios, observed a reduction in TSF as the concentrate inclusion in diets increased. The authors described that the increase in the dietary concentrate level resulted in lower TSF due to the high energy density of the diets. In the present work, despite was observed higher DMI with the different levels of concentrate inclusion, the TSF not changed, indicating that the time spent with feeding does not necessarily determine the magnitude of intake.

Although it has been observed similarity between the variables related to TSF, reducing TSR is result of the physicochemical characteristics of the dietary fiber included in the feed in this study and can be explained by the fact that replacement of sugarcane with concentrate change the dietary fiber characteristics. According to Van Soest (1994), TSR is influenced by the nature of the diet and is probably proportional to the level of cell wall in the diet mass, being influenced by the consumption of NDF (WELCH and HOOPER, 1988). As for feed, NDF value is linked to the cell wall thickness, which influences the rumination time, since the animals will spend more time performing the process of reducing food particles (VAN SOEST, 1994). This activity allows regurgitation, chewing, salivation, and the passage of the previously ingested food into the rumen (LIMA et al., 2014).
Sugarcane has low-digestibility (rich in NDF) and, as a consequence, animals fed with higher levels of sugarcane spent more time ruminating. On the other hand, the concentrate foods reduce the rumination time, behavior observed in this study with the inclusion of this ingredient. Rumination activity in adult animals takes around 8 hours per day (variations from 4 to 9 hours) (VAN SOEST, 1994). In the present study the time spent on rumination reduced from 8.25 for 5.93 hours with inclusion of concentrate in the diets.

The TSI is a reflection of the other activities, meaning that when there is less time consumed by feeding and rumination, the TSI is extended (Figure 2). When animals spend less time feeding and/or ruminating, this behavior is normal and expected. Canizares et al. (2014) also observed a linear reduction for TSI with increasing levels of sugarcane inclusion for milk goats.

According to Ortêncio Filho et al. (2001), the time destined for idling varies wich to the circadian cycle of the species and is related to the feeding and rumination behavior. The behavioral activities of animals are mutually exclusive and one activity compensates another (COSTA et al., 2003). Gonçalves et al. (2001) observed a reduction in TSR with the concentrate inclusion and consequently the TSI was longer in diets for milk goats. 
Figure 2. Ingestive behavior of buffaloes.

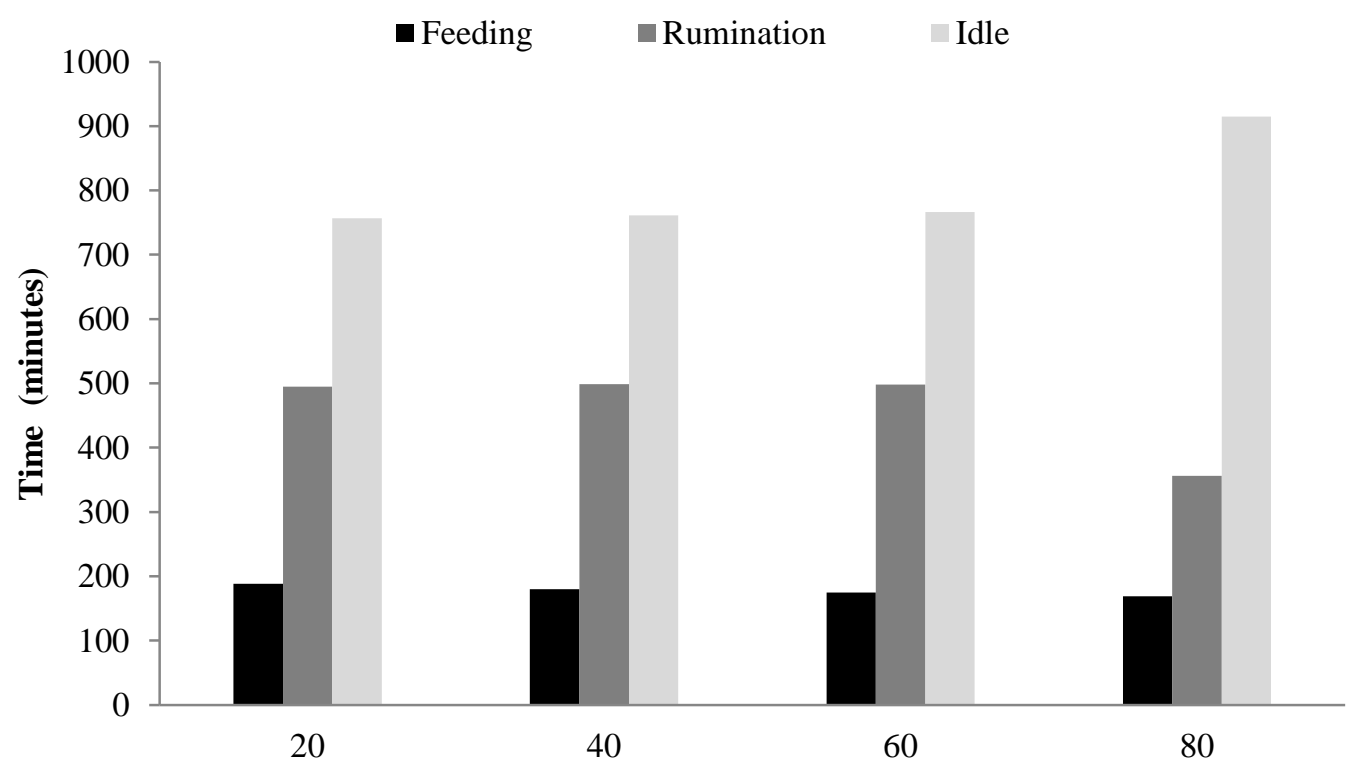

Concentrate Levels (\%)

In the present study, the feed and rumination efficiencies of dry matter increased linearly $(P<0.05)$ with increasing levels of concentrate inclusion. The meal dynamic change between treatments. The meals number, duration of meals and breaks between meals increased linearly $(P<0.05)$ with the inclusion of higher concentrate levels in the diets (Table 4).

Table 4. Feed efficiency (FE) and rumination efficiency (RE) and meal dynamic of buffaloes fed increasing levels of concentrate in sugarcane based diets.

\begin{tabular}{|c|c|c|c|c|c|c|c|}
\hline \multirow{2}{*}{ Items } & \multicolumn{4}{|c|}{ Concentrate levels (\%) } & \multirow[b]{2}{*}{ SEM } & \multicolumn{2}{|c|}{$P$ value } \\
\hline & 20 & 40 & 60 & 80 & & Linear & Quadratic \\
\hline $\mathrm{FE}_{\mathrm{DM}}(\mathrm{kg} \mathrm{DM} / \mathrm{h})^{1}$ & 1.81 & 2.23 & 2.56 & 2.60 & 0.12 & 0.01 & 0.37 \\
\hline $\mathrm{RE}_{\mathrm{DM}}(\mathrm{kg} \mathrm{DM} / \mathrm{h})^{2}$ & 0.68 & 0.80 & 0.86 & 1.24 & 0.06 & 0.00 & 0.05 \\
\hline Meals (number) & 14.17 & 14.00 & 9.67 & 9.67 & 0.57 & 0.00 & 0.90 \\
\hline Duration $(\min )^{4}$ & 13.38 & 13.29 & 18.76 & 18.52 & 1.10 & 0.03 & 0.97 \\
\hline Breaks $(\min )^{5}$ & 83.24 & 84.87 & 120.70 & 123.51 & 5.29 & 0.00 & 0.94 \\
\hline
\end{tabular}

SEM standard error of the mean

$\mathrm{DM}$ - dry matter; $\mathrm{FE}_{\mathrm{DM}}$ - feed efficiency of $\mathrm{DM} ; \mathrm{RE}_{\mathrm{DM}}$ - rumination efficiency of $\mathrm{DM}$

${ }^{1} \hat{Y}=1.62+0.27 X ;{ }^{2} \hat{Y}=0.46+0.17 X ;{ }^{3} \hat{Y}=16.33-0.089 X ;{ }^{4} \hat{Y}=10.76+0.104 X ;{ }^{5} \hat{Y}=63.92+0.783 X$

The increased levels of concentrate caused an increase in DMI and consequently in the feeding efficiency. This behavior might have been caused by the intake of concentrate, rich in non-fibrous carbohydrates, capable of providing a more efficient ingestion. According to Santana Júnior et al. (2013), the feed efficiency represents the speed of ingestion of nutrients as a function of the time. The effects observed in the present study for feed and rumination efficiencies it is associated to greater $\mathrm{DMI}$ and the reducing time spent in rumination with inclusion of concentrate in the diets. When a ruminant ingests food, they chew it superficially, transporting it to the reticulum. After some time, this food returns to its mouth for rumination, which is an activity that reduces the food particle size.

The total rumination time is directly correlated with the size of the particles present in the rumen and with the fiber content of the 
ingested nutrient (MENDES et al., 2015). Higher levels of sugarcane result in long ruminating and, consequently, lower rumination efficiency. This result can be explained by the larger proportion of slowly digestible particles found in the fibrous carbohydrates present in sugarcane. According to Eustáquio Filho et al. (2014), the efficiency of rumination can be reduced in high-fiber diets due to the greater difficulty of reducing the particle size of fibrous materials.

Burger et al. (2000), working with Holstein calves fed diets with different concentrate levels, also observed a linear increase for $F E$ and $R E_{D M}$ as the concentrate levels in the diet were elevated. The authors observed 1.76 and $0.374 \mathrm{~kg} \mathrm{DM} / \mathrm{h}$ for $\mathrm{FE}$ and $\mathrm{RE}_{\mathrm{DM}}$ for $60 \%$ of concentrate in the diet, lower to observed in the present study. According to De la Cruz et al. (2014), the buffaloes are more efficient in transforming the diet and may be due to this species slow, efficacious chewing motion that involves more developed muscle fibres for rumination than in the case of cattle, including the digastric muscle, the masseter muscle, the pterygoid muscle and even the tongue (VEGA et al., 2010). According to Napolitano et al. (2013), other important features include its larger corporal volume, slower movement, smaller outflow rate and higher bacterial activity.

Pearson and Smith (1994) observed that the cattle tended to chew more quickly than the buffalo. The authors observed slight tendency for the buffalo to swallow less frequently and chew each bolus more times than the cattle. Diets containing a high concentration of grain has gained attention because of its economic impact. Still, grain overload in feedlot animals can cause digestive disorders. In fact, digestive disorders, including ruminal acidosis, are second only to respiratory diseases in depressing animal performance and production efficiency (HERNÁNDEZ et al., 2014). However, the buffaloes in present study did not present digestive disorders with the concentrate inclusion in the diets.

A meal is defined by a long sequence of feeding. When it is stopped for several minutes the previous meal is defined (CARVALHO; MORAES, 2005). The number of meals can be an indicator of diet quality. In the present study, the number of meals was negatively related to meals length (duration) and intervals between meals (breaks).
Animals fed increasing levels of concentrate had fewer meals and more time in the trough. The increase in the duration meals was caused by the greater supply of concentrate to the animals, so they needed more time to consume the available supplement, without effect filling. This shows that diets with higher levels of concentrate were in fact more palatable and with more energy density, because although they had greater DMI average (Figure 1) in relation to the other diets, the number of meals was lower, reflecting at long breaks. Long breaks between meals reflect the satiety. On the other hand, the animals fed with higher levels of sugarcane consumed meals more frequently than the others. According to Roche et al. (2008), this behavior is associated with the concentration of circulating metabolites (i.e., the metabolic energy concentration), which provides orexigenic signals to the neurohormonal system, signaling the start of a new meal. Shorter meals reflect the fill caused by the larger proportion of slowly digestible particles and lower rate of passage. Eustáquio Filho et al. (2016), working with lambs fed diets with $50 \%$ sugarcane and $50 \%$ concentrate, reported that the quality of the diet resulted in shorter and more frequent meals, similar to observed in the present work in diets with greater proportion of sugarcane. In this case, physical satiety prevents animal from reaching physiological satiety and the input of nutrients is restricted to a small portion of the daily dietary requirements.

\section{Conclusion}

Increasing levels of concentrate up to $80 \%$ in sugarcane based diets influence directly the feeding behavior of buffaloes resulting in fewer daily meals and more time in the trough, improving the feeding and rumination efficiencies.

\section{Acknowledgments}

We sincerely thank the Brazilian Scientific and Technological Research Council (CNPq) and Pernambuco Research Foundation (FACEPE) for research funding.

\section{Statement of Animal Rights}

The management and care of animals were performed according to the guidelines and recommendations of the Committee of Ethics on Animal Use (CEUA) of the Federal Rural University of Pernambuco (UFRPE). 


\section{References}

ARAÚJO, K.B.S.; RANGEL, A.H.M.; FONSECA, F.C.E.; AGUIAR, E.M.; SIMPLÍCIO, A.A.; NOVAES, L.P.; JUNIOR, D.M.L. Influence of the year and calving season on production, composition and mozzarella cheese yield of water buffalo in the State of Rio Grande do Norte, Brazil. Italian Journal of Animal Science, v.11, n.16, p. 87-91, 2012. https://doi.org/10.4081/ijas.2012.e16

BERNARDES, O. Buffaloes breeding in Brasil. Italian Journal of Animal Science, v.6, Suppl.2, p.162-167, 2007. https://doi.org/10.4081/ijas.2007.s2.162

BÜRGER, P.J.; PEREIRA, J.C.; QUEIROZ, A.C.; COELHO DA SILVA, J.F.; VALADARES FILHO, S.C.; CECON, P.R.; CASALI, A.D.P. Comportamento ingestivo em bezerros holandeses alimentados com dietas contendo diferentes níveis de concentrado. Revista Brasileira de Zootecnia, v.29, n.1, p.236-242, 2000. https://doi.org/10.1590/S1516-

$\underline{35982000000100031}$

CANIZARES, G.I.L.; GONÇALVES, H.C.; RODRIGUES, L.; MARQUES, R.O.; KOMIYAMA, C.M.; MEDEIROS, B.B.L.; GOMES, H.F.B.; ARRUDA, G.M.M.F. Ingestive behavior of dairy goats fed increasing levels of sugarcane in replacement of corn silage. Revista Brasileira de Zootecnia, v.43, n.12, p.648-653, 2014. https://doi.org/10.1590/S1516-

$\underline{35982014001200004}$

CARVALHO, P.C.F.; MORAES, A. Comportamento ingestivo de ruminantes: bases para o manejo sustentável do pasto. Manejo Sustentável em Pastagem. Paraná, 2005.

CORREA, C.E.S.; PEREIRA, M.N.; OLIVEIRA, S.G.; RAMOS, M.H. Performance of Holstein cows fed sugarcane or corn silages of different grain textures. Scientia Agricola, v.60, n.4, p. 621-629, $2003 . \quad$ https://doi.org/10.1590/s0103$\underline{90162003000400003}$

COSTA, C.O.; FISCHER, V.; VETROMILLA, M.A.M.; BAES, C.; MORENO, E.X.F. Comportamento ingestivo de vacas Jersey confinadas durante a fase inicial da lactação. Revista Brasileira de Zootecnia, v.32, n.2, p. 418-424, 2003. https://doi.org/10.1590/S1516$\underline{35982003000200021}$
DE LA CRUZ, L.A.; LEGARRETA, I.G.; NECOECHEA, R.R.; SANTIAGO, P.R.; MEDINA, P.M.; GONZALEZ, R.H.; ROJAS, D.M. The behaviour and productivity of water buffalo in different breeding systems: a review. Veterinary Medicine, v.59, n.4, p. 181193, 2014. https://doi.org/10.17221/7479VETMED

DETMANN, E.; SOUZA, M.A.; VALADARES FILHO, S.C.; QUEIROZ, A.C.; BERCHIELLI, T.T.; SALIBA, E.O.S.; CABRAL, L.S.; PINA, D.S.; LADEIRA, M.M.; AZEVEDO, J.A.G. Métodos para análise de alimentos. Rio de Janeiro, 2012.

EUSTÁQUIO FILHO, A.; CARVALHO, G.G.P.; PIRES, A.J.V.; SILVA, R.R.; SANTOS, P.E.F.; MURTA, R.M.; PEREIRA, F.M. Ingestive behavior of lambs confined in individual and group stalls. Asian Australasian Journal of Animal Science, v.27, n.2, p.284-289, 2014. https://doi.org/10.5713/ajas.2013.13212

EUSTÁQUIO FILHO, A.; CARVALHO, G.G.P.; PIRES, A.J.V.; SILVA, R.R.; SANTOS, P.E.F.; MURTA, R.M.; PEREIRA, F.M.; CARVALHO, B.M.A.; MARANHÃO, C.M.A.; RUFINO, L.M.A.; SANTOS, S.A.; PINA, D.S. Intake and ingestive behavior in lambs fed lowdigestibility forages. Tropical Animal Health and Production, v.48, n.7, p.1315-1321, 2016. https://doi.org/10.1007/s11250-016-1090-x

GONÇALVES, A.L.; LANA, R.D.P.; RODRIGUES, M.T. Padrão nictemeral do $\mathrm{pH}$ ruminal $\mathrm{e}$ comportamento alimentar de cabras leiteiras alimentadas com dietas contendo diferentes relações volumoso: concentrado. Revista Brasileira de Zootecnia, v.30, n.6, p.1886-1892, $2001 . \quad$ https://doi.org/10.1590/S151635982001000700027

HALL, M.B. Calculation of non-structural carbohydrate content of feeds that contain nonprotein nitrogen. Florida, 2000.

HERNÁNDEZ, J.; BENEDITO, J.L.; ABUELO, A.; CASTILLO, C. Ruminal acidosis in feedlot: from aetiology to prevention. The Scientific World Journal, ID702572, p.8, 2014. https://doi.org/10.1155/2014/702572

LICITRA, G.; HERNANDEZ, T.M.; VAN SOEST, P.J. Standardization of procedures for nitrogen fractionation of ruminant feeds. Animal Feed Science and Technology, v.57, n.4, p.347-358, 
1996.

https://doi.org/10.1016/0377-

$\underline{8401(95) 00837-3}$

LIMA, C.B.; COSTA, T.G.P.; NASCIMENTO, T.L.; LIMA JÚNIOR, D.M.; SILVA, M.J.M.S.; MARIZ, T.M.A. Comportamento ingestivo e respostas fisiológicas de ovinos em pastejo no semiárido. Journal of Animal Behaviour and Biometeorology, v.2, n.1, p.26-34, 2014. https://doi.org/10.14269/2318-1265.v02n01a05

MARIZ, L.D.S.; VALADARES FILHO, S.C.; DETMANN, E.; PEREIRA, L.G.R.; MARCONDES, M.I.; SANTOS, S.A.; VILLADIEGO, F.A.C.; ZANETTI, D.; PRADOS, L.F.; NUNES, A.N. Intake and ruminal digestion determined using omasal and reticular digesta samples in cattle fed diets containing sugar cane in natura or ensiled sugar cane compared with maize silage. Livestock Science, v.155, n.1, p.71-76, 2013. https://doi.org/10.1016/i.livsci.2013.04.003

MENDES, F.B.L.; SILVA, R.R.; CARVALHO, G.G.P.; SILVA, F.F.; LINS, T.O.J.D.; SILVA, A.L.N.; MACEDO, V.; FILHO, G.A.; SOUZA, S.O.; GUIMARÃES, J.O. Ingestive behavior of grazing steers fed increasing levels of concentrate supplementation with different crude protein contents. Tropical Animal Health and Production, v.47, n.2, p. 423-428, 2015. https://doi.org/10.1007/s11250-014-0741$\underline{z}$

MERTENS, D.R. Gravimetric determination of amylase-treated neutral detergent fiber in feeds with refluxing in beakers or crucibles: collaborative study. Journal of AOAC International, v.85, n.6, p. 1217-1240, 2002.

NAPOLITANO, F.; PACELLI, C.; GRASSO, F.; BRAGHIERI, A.; DE ROSA, G. The behaviour and welfare of buffaloes (Bubalus bubalis) in modern dairy enterprises. Animal, v.7, n.10, p.1704-1713, 2013.

https://doi.org/10.1017/S1751731113001109

ORTÊNCIO FILHO, H.; BARBOSA, O.R.; SAKAGUTI, E.S.; ONORATO, W.M.; MACEDO, F.A.F. Efeito da sombra natural e da tosquia no comportamento de ovelhas das raças Texel e Hapshire Down, ao longo do período diurno, no nordeste do estado do Paraná. Acta Scientiarum Animal Science, v.23, n.4, p.981-993, 2001. https://doi.org/10.4025/actascianimsci.v23i0.265 $\underline{5}$
PAUL, S.S. Nutrient requirements of buffaloes. Revista Brasileira de Zootecnia, v.40, supl. esp., p.93-97, 2011.

PAUL, S.S.; LAL, D. Nutrient requirements of buffaloes. Delhi: Satish Serial Publishing House, 2010.

PEARSON, R.A.; SMITH, D.G. The effects of work on food intake and ingestive behavior of draught cattle and buffalo given barley straw. Animal Production, v.58, n.3, p.339-346, 1994. https://doi.org/10.1017/S0003356100007273

ROCHE, J.R.; BLACHE, D.; KAY, J.K.; MILLER, D.R.; SHEAHAN, A.J.; MILLER, D.V. Neuroendocrine and physiological regulation of intake with particular reference to domesticated ruminant animals. Nutrition Research Review, v.21, n.2, p.207-234, 2008.

https://doi.org/10.1017/S0954422408138744

SANTANA JÚNIOR, H.A.; FIGUEIREDO, M.P.; CARDOSO, E.O.; MENDES, F.B.L.; ABREU FILHO, G.; PINHEIRO, A.A.; LISBOA, M.M.; LUZ, Y.S.; VIANA, P.T.; FERREIRA, A.H.C.; RECH, C.L.S. Crude glycerin in diets for lactating cows grazing on tropical pasture: Ingestive behavior. Semina: Ciências Agrárias, v.34, n.3, p. 1339-1352, 2013.

SILVA, R. R.; PRADO, I.N.; CARVALHO, G.G.P.; JUNIOR, H.A.S.; SILVA, F.F.; DIAS, D.L.S. Efeito da utilização de três intervalos de observações sobre a precisão dos resultados obtidos no estudo do comportamento ingestivo de vacas leiteiras em pastejo. Ciência Animal Brasileira, v.9, n.2, p.319326, 2008.

SILVA, T.M.; OLIVEIRA, R.L.; NASCIMENTO JÚNIOR, N.G.; PELLEGRINI, C.B.; TRAJANO, J.S.; ROCHA, T.C.; BEZERRA, L.R.; BORJA, M.S. Ingestive behavior and physiological parameters of goats fed diets containing peanut cake from biodiesel. Tropical Animal Health and Production, v.48, n.1, p.59-66, 2016. https://doi.org/10.1007/s11250-015-0920-6

VAN SOEST, P.J. Nutritional ecology of the ruminant. Ithaca: Cornell University, 1994.

VEGA, R.S.A.; DEL BARRIO, A.N.; SANGEL, P.P.; KATSUBE, O.; CANARIA, J.C.; HERRERA, J.V.; LAPITAN, R.M.; ORDEN, E.A.; FUJIHARA, T.; KANAI, Y.. Eating and rumination behaviour in 
Brahman grade cattle and crossbred water buffalo fed on high roughage diet. Animal Science Journal, v.81, n.5, p.574-579, 2010. https://doi.org/10.1111/j.1740-

$\underline{0929.2010 .00784 . x}$

WELCH, J.G.; HOOPER, A.P. Ingestion of feed and water. The ruminant animal: digestive physiology and nutrition. Reston: Englewood Cliffs, 1988. 